\title{
Searching for ethos in Family Health Strategy: a bioethical investigation
}

Luís Claudio de Souza Motta ${ }^{1}$, Selma Vaz Vidal ${ }^{2}$, Andréia Patrícia Gomes ${ }^{3}$, Túlio César Correia Lopes ${ }^{4}$, Lucas Rennó ${ }^{5}$, Renato Miyadahira ${ }^{6}$, Rodrigo Siqueira-Batista ${ }^{7}$

\begin{abstract}
This is a qualitative and quantitative empirical study seeking to identify and critically describe bioethical issues in primary health care from the perspective of members of Family Health Strategy (ESF) teams in a city in the mountainous region of the state of Rio de Janeiro, Brazil. It also sought to detect the degree of theoretical approximation of professionals regarding the basics of ethics and bioethics, based on principialist theory. A semi-structured questionnaire was adopted as data collection instrument. The responses were categorized into aspects related to (i) ethical/bioethical conflicts in relation to staff and users; (ii) ethical/bioethical conflicts in the process of work and coexistence among team members; and (iii) misconceptions regarding the concepts of basic (bio)ethics and deontology. Although apparently less obvious, such matters concerning the scope of primary health care compromise the work process and the promotion of comprehensive care for users of the SUS. Keywords: Primary health care. Ethics. Bioethics.
\end{abstract}

\section{Resumo}

\section{Em busca do ethos da Estratégia Saúde da Família: uma investigação bioética}

Estudo empírico, quali-quantitativo, em que se buscou identificar e caracterizar questões bioéticas na atenção primária à saúde - na perspectiva dos membros das equipes de ESF em um município da Região Serrana do Rio de Janeiro, Brasil, buscando-se descrevê-las criticamente. Procurou-se também detectar o grau de aproximação teórica dos profissionais em relação a conceitos básicos de ética e bioética, tendo como base a teoria principialista. Adotou-se o questionário semiestruturado como instrumento de coleta de dados. As respostas obtidas foram categorizadas em aspectos relacionados a (i) conflitos éticos/bioéticos em relação à equipe e aos usuários; (ii) conflictos éticos/bioéticos en el processo de trabalho e convivência entre os membros da equipe; (iii) equívocos quanto à compreensão dos conceitos básicos de (bio)ética e deontologia profissional. Contudo, mesmo que aparentemente menos evidentes, tais questões atinentes ao âmbito da atenção primária à saúde comprometem o processo de trabalho e a promoção da integralidade no cuidado ao usuário do SUS.

Palavras-chave: Atenção primária à saúde. Ética. Bioética.

\section{Resumen}

\section{En busca del ethos de la Estrategia Salud de la Familia: una investigación bioética}

Estudio empírico, cualitativo y cuantitativo, donde se trató de identificar y caracterizar las cuestiones de bioética en la atención primaria de salud - desde la perspectiva de los miembros de los equipos de la ESF en una ciudad en la región montañosa de Río de Janeiro, Brasil, buscando describir críticamente. También trató de detectar el grado de aproximación teórica de los profesionales con respecto a los fundamentos de la ética y la bioética, en base a la teoría principialista. Adoptó un cuestionario semi-estructurado como un instrumento de recolección de datos. Las respuestas se clasificaron en los aspectos relacionados con (i) conflictos éticos/ bioéticos en relación con el personal y los usuarios; (ii) conflictos éticos/bioéticos éticos en el proceso de trabajo y la convivencia entre los miembros del equipo; (iii) conceptos erróneos acerca de la comprensión de los conceptos básicos (bio)ética y la ética profesional. Sin embargo, aunque aparentemente menos obvio, esas cuestiones relativas al ámbito de la atención primaria de salud se comprometen el proceso de trabajo y la promoción de la integridad en la atención a los usuarios del SUS. Palabras-clave: Atención primaria de salud. Ética. Bioética.

\section{Aprovação CEP Centro Universitário Serra dos Órgãos - Protocolo 477-10}

1. Doutorando Icsmotta@hotmail.com - Universidade Federal do Rio de Janeiro (UFRJ) e Centro Universitário Serra dos Órgãos (Unifeso), Rio de Janeiro/RJ, Brasil 2. Doutora vazvidal@yahoo.com.br - Universidade Federal do Rio de Janeiro (UFRJ) Rio de Janeiro/RJ, Brasil 3. Doutora andreiapgomes@gmail.com 4. Graduando tuliocesarlopes@gmail.com 5. Graduando lucasrenno87@gmail.com 6. Graduando mh.renato@yahoo.com - Universidade Federal de Viçosa (UFV), Minas Gerais/MG, Brasil 7. Doutor rsbatista@ufv.br Universidade Federal do Rio de Janeiro/UFRJ e Universidade Federal de Viçosa (UFV), Minas Gerais/MG, Brasil.

\section{Correspondência}

Luis Claudio de Souza Motta - Avenida Alberto Torres, no 111 - Alto CEP 25964-004. Teresópolis/RJ, Brasil. 
The promulgation of the Constitution of 1988 and the introduction, through Law 8080, of the Sistema Único de Saúde (SUS) [Unified Health System], represented, from a legal viewpoint, the highest stage of a historical process of democratic struggle for the universal right to health care ${ }^{1}$. Since then, a series of discussions and regulations have been proposed, attempting to put the SUS legal proposal into practice. In this sense, the redirection of primary attention, point of initial contact and main entrance door of individuals and families to the health system has become one of the strategic points for the consolidation of the SUS; highlighting the introduction of the Programa de Saúde da Família (PSF) [Family Health Program] in 1994, later on re-dimensioned as Estratégia Saúde da Família (ESF) [Family Health Strategy], the main point for system reorganization ${ }^{2-5}$. In 2006, with the introduction of the National Policy for Primary Health Care, the aim of primary care was broadened, reaffirming the ESF as a model of implementation of a new logic for the organization of the Brazilian health care system ${ }^{6,7}$. This system has demanded modern practices and work strategies from health professionals.

This scenario highlights the role of bioethics, which must exceed the codes of conduct or moral relations of coexistence which underlie and often capture mechanisms of subjection and the exercise of power, proposing respect and for and protection of all beings, human or not, and their natural habitats ${ }^{8-10}$. The relevance of bioethical debate is that it gains resonance in diverse contexts, including work in the health field, making it the central discipline in the education of health professionals ${ }^{11}$. Added to this fact is that in today's society individuals should have various skills in addition to those previously required ${ }^{12}$, combining techniques with ethics - which makes relevant the need for expansion and optimization of venues for the discussion of ethics and bioethics in the implementation of current educational contexts.

Initially, the theoretical proposal of Beauchamp and Childress, published in 1979 and entitled "Principles of biomedical ethics", continued the discussion of the Belmont Report, the first attempt to systematize basic principles aimed at decision making and moral conflict resolution within the area of health. The concept of bioethics has expanded over the past few years, extending to every kind of life, in line with Potter's original design. But despite its broad context, the very etymology of the word bioethics, in the strictest sense, refers to the phenomena referred to in the health sciences and biotechnolo- gies ${ }^{13}$, and so it was incorporated by principialism as a theoretical current ${ }^{14}$ and widely discussed in the health context.

Health care, previously limited to assistance centered on hospital practices for drug and healing purposes, started to be viewed as a right of every citizen and a duty of the State, in terms of actions of education, promotion, prevention, protection and rehabilitation. This process allowed new bioethical issues to emerge, in an ethos up to that time almost invisible to ethical reflection: primary care ${ }^{15,16}$. From this perspective, it is possible to recognize, as well described by Zoboli, that the contributions of bioethics to primary care are still poorly characterized; as for a long time, critical discussions on tertiary assistance and biotechnology were prioritized, highlighting the hospital as the privileged locus of debate on the beginning and end of life, organ donation, transplants and new therapeutic approaches, among others ${ }^{10,11}$.

In rare discussions, the implications of bioethical issues were addressed at other levels of health care. In addition, as equally described by the above-mentioned author, it should be mentioned that 1) health problems differ according to the levels of actions and procedures provided; 2 ) the objects of ethics (users, family members and health professionals) are also different and may have less autonomy than in the case of hospitalized patients; 3 ) the scenario of each type of health service has peculiarities and; 4) the solutions for similar ethical problems may differ, considering the different space-time of health care ${ }^{17-20}$.

In view of this, the present study aims to describe the (bio)ethical problems experienced by members of family health teams (doctors, nurses, nursing technicians and others) in their daily primary care practices. Moreover, specific purposes, such as the design of the above-mentioned problems and identification of the awareness of principles on the part of staff members, were also evaluated in ter$\mathrm{ms}$ of the basics of ethics and bioethics, based on current principialist theory, originally intended as a medical bioethics, i.e. approximating the area of health context. It is known that the principles proposed by this theory are not adequate for discussing, for example, the bioethical issues in the sphere of public health ${ }^{21}$; but they were considered by the authors as a theoretical current incorporating that which was most discussed in undergraduate health. The term ethos here assumes the sense of the Greek word (' $n \theta 0 \varsigma)$, the original meaning of which, in the Homeric world, was "harboring". 


\section{Materials and methods}

\section{Study scenario and subjects}

The study was conducted in the municipality of Teresópolis, with approximately 163,746 inhabitants and a territorial area of $770.51 \mathrm{~km}^{2}$, constituting the mountainous region of Rio de Janeiro state (RJ, Brazil). According to reports of the Ministério da Saúde (MS) [Brazilian Ministry of Health] ${ }^{22}$, Teresópolis had twelve ESF teams with 76 Community Health Workers, representing $24.98 \%$ coverage. The municipality was chosen by convenience, considering researchers' access to the Unidades de Saúde da Família (USF) [Family Health Units]. Data gathering occurred from February to March, 2011.

The study subjects included professionals/ workers at three local USF. Selection of USF was random, but with the preliminary condition that the selected units have complete ESF teams (in fact, there were eight complete USF units at the moment of selection). All ESF team professionals were invited to participate in the study, except those who had administrative positions or who were not part of the health care staff designated by the $\mathrm{MOH}^{23}$.

\section{Study design and data collection}

An empirical, qualitative and quantitative study was conducted, aiming to identify and characterize bioethical issues concerning health care, describing ${ }^{24}$ and interpreting them critically, allowing rational and unbiased analysis of the observed moral conflicts ${ }^{21}$. The field of this study is social and, due to the characteristics of the object of investigation, the theoretical, instrumental and methodological underpinnings of qualitative research, which deals with the universe of meanings, reasons, aspirations, beliefs, values and attitudes, corresponding to a deeper space of relations, processes and phenomena that cannot be reduced to variables operationalization ${ }^{25,26}$, were employed.

The semi-structured questionnaire was adopted as a data gathering tool, following the recommendations of the literature that it should be mixed, in other words, use both open-ended and closed-ended questions. It is well known that open-ended questions allow freedom of thought and that the varied answers permit possible identification of meanings. In contrast, closed-ended questions allow fast and easy answering, as well as subsequent quantification ${ }^{27}$.
The questionnaire included 25 questions, divided into three main sections: 1 ) general educational characteristics and time of employment of the professional at the ESF, 2) bioethical problems faced by the team, and 3) understanding of ethics and bioethics principles. As regards the "general educational characteristics and time of employment at the ESF," the questionnaire contained closed-ended questions on the academic formation of the professionals, time (in years) of undergraduate study, time (in years) of work in the health area and time (in years) of work as an ESF professional.

The section, "bioethical problems faced by the team," contained open questions in which professionals were to describe: one or more bioethical situations experienced at the USF; the consequences; how the team approached the issue; and the solution, if applicable, to the problem. On the third section of the questionnaire, knowledge of ethics and bioethics principles, there were questions on the understanding of ethics and bioethics concepts, the possibility of teaching such knowledge, if they should be registered in their work routines and if there was interest in learning more on such themes.

The selected teams were contacted in their USF for explanation of the study proposal and, subsequently, for formalization of invitation and participation, as well as clarification on the investigation objectives. As soon as the professional consented to participate, he or she received the semi-structured questionnaire to be filled out. The investigator interfered the least possible, orientating and stimulating each participant in the preparation of answers.

\section{Data analysis \\ General characteristics of participants}

The questionnaire was answered within an average period of 45 minutes by 31 USF professionals: 13 Community Health Agents (CHA - 41.9\%); 2 Oral Hygiene Technicians (OHT - 6.5\%); 2 Dentists (D - 6.5\%); 5 Physicians (PHY - 16.1\%); 5 Nurses ( $\mathrm{N}-$ $16.1 \%$ ) and 4 Nursing Technicians (NT $-12.9 \%$ ).

To guarantee privacy of identity of the participants, each questionnaire was coded by numbers associated to an acronym; codes were used in any reference to participants/questionnaires.

Nearly all professionals who answered the questionnaires were women $(n=29)$. Regarding the participants' level of education, $19(61.3 \%)$ had high school level and 12 (38.7\%) had a university degree, with specialization (completed or attending). The participants' time of direct work in primary care 
was: 0 to 1 year $(7$, or $23.0 \%)$; 1 to 2 years $(6$, or $19.0 \%) ; 2$ to 5 years $(5$, or $16.0 \%) ; 6$ to 10 years $(6$, or $19.0 \%) ; 11$ to 15 years (5, or $13.0 \%)$; another 3 professionals had not yet completed one year. Based on the responses, it was noticed that the upper and mid-level professionals remained less time working in primary care.

It has been observed that few professionals work at ESF for a long time, corroborating previous studies that mention high turnover of professionals. In other words, non-commitment of professionals to primary care and inadequate working conditions, related in the literature and resulting from problems of professional depreciation, job instability, lack of motivation with working conditions and lack of adequate USF infrastructure, and others ${ }^{4,28-32}$. Such a context becomes even more complex in the face of different ESF management approaches, such as outsourcing by state-owned foundations and Social Organizations (SO) ${ }^{30}$.

The analysis of answers was conducted using Bardin's content analysis technique, specifically thematic analysis, due to its adaptation to qualitative investigation in the health area. Following the systematic reading of answers, three stages were carried out: 1) pre-analysis; 2) material exploration and; 3 ) results processing, inference and interpretation ${ }^{33}$, respecting the order of arrangement of the sections of the questionnaire. During the first two stages, pre-analysis and exploration of the material, the thorough and careful reading of each of the participants' responses was undertaken, seeking to identify significant issues in the object of study and its points of approach. In the next step, treatment of results, inference and interpretation, the data were grouped according to the convergence of themes or answers being highlighted during the interpretation and the commonalities and possible inconsistencies, culminating in organizing them into aggregator unit directions (categorization). Further data quantification was carried out using the software program Epi InfoTM, version 3.5.2.

Bioethical problems mentioned by respondents relate to two main categories of analysis: 1) conflicts between health teams and users, and 2) conflicts between the respondents and the members of health teams; both are presented and discussed later in this article.

\section{Ethical aspects}

The present study was submitted to analysis and approved by the Research Ethics Committee of the Se- rra dos Órgãos University Center, in agreement with resolution by Conselho Nacional de Saúde CNS/MS number 196/96 [National Health Council], which then prevailed. Initial permission from the General Office of Health of Teresópolis, RJ was obtained. All participants willingly signed the Informed Consent Form (ICF) ${ }^{34}$.

\section{Results and discussion}

Presentation of results will be made by questionnaire section.

\section{Aspects concerning main ethical/bioethical problems identified by health teams}

Among the 18 answers referring to bioethical problems, two main categories were considered: 1) conflicts between health care teams and users disregarding privacy or the confidentiality of users and/or relatives and a case of physical assault of a community health agent by a community member, and 2 conflicts between team members: disrespect, criticism and verbal aggression between professionals, occurrence of discussions in the presence of users, performance of tasks not belonging to the professional's job description and disrespect for interdisciplinary behavior.

When participants were asked to describe situations experienced in the USF involving problems of a bioethical nature, some (9) of the professionals answered that they had not experienced or did not remember situations of an ethical/bioethical order at the ESF; 4 participants, 1 nursing technician, 1 oral hygiene technician and 2 community health agents did not answer this question. Consequently, 18 professionals reported ethical conflicts. Considering the group that answered the question affirmatively, the answers revealed a certain difficulty in identifying situations involving problems of a bioethical nature, demonstrating a certain confusion related to organization or planning of the staff work process:

"Team relationships and the dental service were introduced at the ESF in March of 2010 and up to now they are isolated. First they announce the doctor and the nurse and then they "remember" the dentist (...). The problem is complex, no matter how hard we try to modify this vision, we do not find support" D12;

\footnotetext{
"Because of conflict between technicians some vaccines are no longer carried out. The two technicians were warned by the nurse and instructed that it was not to happen again..." PHY3.
} 
This difficulty in identification, and even a certain confusion, can be understood when it is mentioned that in primary health care units, and in situations of less urgency, i.e. emergency, urgency and tension, meetings with users are more frequent. For example, emergency hospitals and intensive care units allow bioethical issues to be more obvious, tempestuous and massive; whereas in primary health care units they emerge more subtly, frequently going unnoticed ${ }^{35}$.

Category 1, conflicts between health care teams and users, refers specifically to privacy and the confidentiality of the information provided to professionals by users and/or relatives, one of the bioethical aspects highlighted by the participants in the investigation, according to answers transcribed below, elaborated by a nurse and a community health agent:

\section{"Lack of confidentiality of some patients' personal} issues" N9;

"HIV positive patient. The community health agent [CHA] unintentionally let information 'leak' without patient permission (...), causing embarrassment and prejudice against the patient by the community" CHA27.

In the bioethics literature, confidentiality is defined as the guarantee of protection of information given personally in confidence and the protection against its non-authorized revelation or the duty of protecting all information concerning a person, e.g. their privacy ${ }^{36,37}$, while privacy is defined by limitation of access to the information of a given person, access to the person herself, to his intimacy or involving questions of anonymity, secrecy, removal or solitude ${ }^{38}$.

Dealing with the privacy and confidentiality of information is an aspect that permeates the teamwork process of ESF, given the difficulty in maintaining privacy in services carried out both at the USF and in patients' residences and in defining to what extent users' and their families' private information observed by professionals, especially by the community health agent, should be shared with the team. It is worth mentioning that information to which the ESF team has access do not exclusively concern users' morbid conditions ${ }^{16,38}$. Privacy imposes on a professional the duty of protecting shared information and preserving patient intimacy. On the other hand, confidentiality is related to the contact between professional and user and must be main- tained in secret, unless its revelation is authorized by the latter ${ }^{39-41}$.

This dimension of the question is particularly significant in the case of community health agents, as these professionals must necessarily belong to the community in which they work. Thus, their social reality is same as that of the users ${ }^{41}$. On account of having greater proximity with patients and frequently entering their residences for home visits, the community agent, in his or her practice practice, requires the incorporation of bioethical principles in their daily interaction with users and respective relatives ${ }^{42,43}$.

According to the principialism of Beauchamp and Childress, which discusses the bioethical principles of autonomy, beneficence, non-maleficence and justice, the bioethical justification for the right to confidentiality is based on respect for personal autonomy ${ }^{24}$. This information has special importance when the revelation of information exposes $a$ patient to legal risks, loss of loving friends and relationships, emotional desolation, discrimination, loss of jobs ${ }^{39,44}$ and other things. The following reflection surfaces at this point: to what extent should this information or these observations involving privacy and confidentiality be discussed by the ESF teams, vis-a-vis which professionals, and how can they be revealed?

Category 2, bioethical problems in relationships between team members (lack of companionship, respect, commitment and collaboration), referring to difficulties in delimiting duties and functions of each ESF team member and respective working field, which result from the incorporation of new professionals and innovations in health care proposals ${ }^{16,44}$. The following quotations corroborate this delimitation:

"Professionals argue in front of patients. (...) They were frightened by what they heard" N6;

"I do not remember at the moment. But we always have interpersonal conflicts within the team" PHY2.

It is worth mentioning that such aspects can interfere in the integrity of primary care to system users. In order for changes to occur in health practices and correct team work, changes in the work relationships of the primary health care team itself are necessary. There is an urgently needed new way of looking at the system user, at the work colleague and at oneself as a health professional ${ }^{5}$. Despite 
attempts to restructure sanitary practices within a proposal that should privilege team work, it is observed that teamwork in primary care still reveals the existence of tension between fragmentation and integration of the work process. Thus, there is a risk of professionals being isolated in their "nuclei of competence," or actions that are carried out in an isolated manner and juxtaposed, thus reproducing different planes of fragmentation in the organization of both work and knowledge, and in the interaction between subjects, professionals and users ${ }^{44}$.

The daily production of health care depends largely on the skills of health workers, as well as the degree of interaction between various professional identities within the ESF ${ }^{2,45}$ and ethical respect among these same professionals. Also extremely important are the interdisciplinary approach and the need for respect and teamwork, allowing as they do further discussion and problem solving, in addition to strengthening the organization and management of services. Yet from this perspective, it is important to emphasize that interdisciplinarity and proposed teamwork (respect for the various ESF professionals) do not seek the unification of knowledge, but rather the complementarity of knowledge within comprehensive care ${ }^{3}$. As for the approach of the teams to the resolution of conflicts that were described in the questionnaire, eight participants reported that the solution adopted was dialog among those involved; 18 did not answer and only 1 mentioned calling the ESF co-ordination when necessary - which had repercussions for the transfer or dismissal of professionals. Four staff members stated that there was no solution to the conflicts.

When asked if "it was necessary to use bibliographical references for the resolution of problems or bioethical conflicts," only 3 professionals (2 physicians and 1 nurse) mentioned consulting their respective codes of practice. Of the others, $17 \mathrm{did}$ not respond, and 11 answered that consultation was not necessary. When asked in the questionnaire about "the consequences of the problems that occurred," they answered that there were negative repercussions in some cases for users in their bonds with the teams, while in other cases, there were harmful repercussions for the relationships between team members, as described below:

"Unpleasant consequences for clients, mainly because they are not in the primary health care unit to witness problems between officers" OHT15;
"Dissatisfaction of the whole team" PHY1;

"Lack of motivation, disunity, fragility in work processes, lack of quality of the work, damage to patients" N9.

Differently from what happens in the hospital environment, the asymmetry between health professionals and ESF users is established in other terms. While in hospital institutions the relations are authoritarian and little questioned by patients due to the "omnipotence" of the health professional (meaning that the hospital is a space of confinement par excellence, typical of disciplinary societies ${ }^{46,47}$, the submission of ESF users is reduced, given that adhesion to the prescribed conducts depends, most of the time, on user deliberation.

The user holds greater making-decision autonomy, and for that reason the clinical gaze in primary care needs to be broadened to favor the understanding of the patient in his or her individuality, complexity, integrity and sociocultural insertion, so that proper pact and co-responsibility takes place in the health care process ${ }^{16}$. It is worth emphasizing the possibility of a high degree of intervention in people's lives, mostly by the community health agent, reproducing, even unintentionally, capture processes urged in the context of control societies ${ }^{48-50}$.

\section{Aspects related to ESF team members' knowledge} of the principles of ethics and bioethics

As this section, the last part of the semi-structured questionnaire, is aimed at detecting the degree of professionals' academic knowledge regarding the principles of ethics and bioethics, we aimed to detect the degree of professionals' approximation to and/or theoretical appropriation of the basics of ethics and bioethics, taking as a basis the principialist theory. The first three questions were: 1) what were the first words that came to their minds when they heard the terms 'ethics' and 'bioethics'? (free evocation or the free association technique); 2) if they knew any principles of 'ethics' and 'bioethics'; and, finally, 3) if they had ever read about principles such as 'respect for autonomy,' 'beneficence,' 'non-maleficence,' 'justice,' 'protection,' and 'compassion,' among others.

Based on the responses, another category of analysis was detected: 1) No distinction, misunderstanding of basic concepts of ethics and bioethics. As for the understanding on the concept of bioethics, it was noticed that many professionals still do not dis- 
tinguish it correctly from the ethics and deontology concept, as shown in Table 1.

Table 1. Understanding of the concept of bioethics.

\begin{tabular}{lcc}
\hline \multicolumn{3}{c}{ What do you mean by 'Bioethics'? } \\
Main responses & $\begin{array}{c}\text { Absolute } \\
\text { frequency }\end{array}$ & Percentage \\
\hline Driving principle of life* & 6 & $19.4 \%$ \\
\hline $\begin{array}{l}\text { Respect for patient/user } \\
\text { Decision about another }\end{array}$ & 3 & $9.7 \%$ \\
individual & 3 & $9.7 \%$ \\
Health ethics & 2 & $6.5 \%$ \\
Team ethics & 2 & $6.5 \%$ \\
\hline Set of standards & 1 & $3.2 \%$ \\
\hline $\begin{array}{l}\text { Decisions that influence } \\
\text { a group }\end{array}$ & 1 & $3.2 \%$ \\
Did not answer & 13 & $41.8 \%$ \\
\hline
\end{tabular}

The following answers illustrate the concept of deontology:

"[Bioethics is] respect for a patient, preserving him from any type of exposure" DHT17;

\section{"[Bioethics is] professional secrecy" CHA20;}

"[Bioethics is] behavior, attitudes, decisions..." CHA27.

In the excerpts below, the reduction of ethics and bioethics to biological aspects or to the sphere of health sciences is observed ${ }^{39}$ :

"[Bioethics] are principles that rule the conduct of biological, health and life processes" D12;

"Ethics, from my point of view, is a condition that governs a citizen's posture in his or her relationship with others. This is bioethics, concerning topics related to the biological life of the individual" PHY5.

At present it is known that bioethics can be conceived in different ways, without limiting it to issues of the health sciences area but, equally, as discourse on the moral implications of human praxis to different extents ${ }^{18}$. According to Kottow, the area concerns a set of principles, arguments and standards that value and ethically legitimize human acts, understanding that these acts profoundly, and mostly irreversibly, in a real or potential way, affect living systems ${ }^{51}$.

In addition, it was noticed that aspects related to environmental questions and to health-environment interrelationships, which are determinants of the prevalence of disease, were not mentioned or correlated with bioethics in the answers. It is also important to consider that environment changes can cause effects on planetary life, and equally, on the health of living beings ${ }^{52}$. However, such aspects should play a primordial role in the reflections and primary care actions of the ESF multidisciplinary team directed to users of the SUS ${ }^{53,54}$. Moreover, these actions should be contextualized and included in the formation of health professionals ${ }^{10,55}$, requiring that a person's exclusive concern with himself or with his species be overcome ${ }^{18}$.

Regarding the assertion contained in question number 21 of the questionnaire, in which is stated that "All health professionals must have their work governed by the principles of ethics and bioethics," participants were asked to refer to their own perception. Next, it was asked if they had already participated in any courses, training workshops or other teaching-learning processes focusing or approaching ethics and bioethics principles.

Although according to answers obtained and listed in Table 2, 25 agreed on the importance of work based on such referential systems, little familiarity on the part of these professionals with those the principles of bioethics was observed. Among the answers obtained, 17 (54.8\%) of the team professionals in the community health agent area responded that they had had no prior participation in teaching-learning activities in aspects related to ethics and bioethics (out of a total of 13 agents, 5 , or $38.0 \%$, answered that they had not participated in prior events on ethics and bioethics). Although explicitly included in the current - Diretrizes Curriculares Nacionais (DCN) ${ }^{56-59}$ [National Curricular Directives] for health sciences graduate programs and recognized as important formation by the participants in this study of professionals, it has been observed that secondary education in health sciences does not address the necessary bioethical reflections for professional formation appropriately or sufficiently. 
Table 2. Participation in courses, workshops or other models of teaching and learning of ethics and bioethics.

\begin{tabular}{lcc}
\hline $\begin{array}{l}\text { Participation in training } \\
\text { activities in ethics and } \\
\text { bioethics }\end{array}$ & $\begin{array}{c}\text { Absolute } \\
\text { frequency }\end{array}$ & Percentage \\
\hline $\begin{array}{l}\text { Did not participate in } \\
\text { training activity }\end{array}$ & 17 & $54.8 \%$ \\
$\begin{array}{l}\text { Yes, organized by the } \\
\text { higher education or } \\
\text { professional council }\end{array}$ & 5 & $16.1 \%$ \\
\hline $\begin{array}{l}\text { Yes, promoted by a public } \\
\text { agency. }\end{array}$ & 3 & $9.7 \%$ \\
$\begin{array}{l}\text { Yes, without specifications } \\
\text { Yes, a technical course of } \\
\text { study }\end{array}$ & 2 & $6.5 \%$ \\
\hline No answer & 1 & $3.2 \%$ \\
\hline
\end{tabular}

Such a scenario raises the question of the relevance of bioethics being included in the curricula of undergraduate and graduate programs, as well as continued education and permanent education processes - which must exceed deontological codes and mere moral relations of good fellowship, which are very often perpetuators of spurious power relationships $47,48,60$. The appropriation of new pedagogical strategies of teaching-learning is of fundamental importance in the formation of health professionals capable of reflecting and deciding about on ethical questions relevant to family health strategy, as well as being of fundamental importance to health care ${ }^{61-63}$.

The three last questions of the instrument were to evaluate whether the study participants considered ethics and bioethics capable of being taught, and to what extent they yearned to improve knowledge in this area of investigation. Analyzing of the responses revealed a certain consensus that ethics and bioethics could be taught and learned 24 affirmative responses; relative frequency $=77.4 \%$, except among 3 professionals who answered that this would not be a possibility and another 4 who left this question blank. As for the wish to learn more on ethics and bioethics there was near consensus of the participants: 26 (relative frequency 83.9\%) answered positively, and only 5 participants did not answer. The answers referring to which modalities they considered proper for ethics and bioethics teaching are shown in Table 3.
Table 3. Preferred modalities for the teachinglearning of ethics and bioethics.

\begin{tabular}{lcc}
\hline \multicolumn{1}{c}{$\begin{array}{c}\text { Teaching ethics and } \\
\text { bioethics, how? }\end{array}$} & $\begin{array}{c}\text { Absolute } \\
\text { frequency }\end{array}$ & Percentage \\
\hline $\begin{array}{l}\text { Yes, life experiences and } \\
\text { workshops }\end{array}$ & 10 & $32.3 \%$ \\
\hline $\begin{array}{l}\text { Yes, without } \\
\text { justification }\end{array}$ & 4 & $29.0 \%$ \\
$\begin{array}{l}\text { Yes, with continuing } \\
\text { education }\end{array}$ & 1 & $3.2 \%$ \\
\hline Did not answer & 4 & $12.9 \%$ \\
No, you can not teach & 3 & $9.7 \%$ \\
\hline
\end{tabular}

\section{Final considerations}

Ethics in family health represents an innovative and restructuring strategy of primary health care and, in the last analysis, of the SUS, in that it transforms a fragmented vision of the human being into an integral conception in the individual, family and collective dimensions. In addition, the understanding of the health-disease process to which users are exposed in primary care broadens the horizon for the awareness of family, community and the environmental reality ${ }^{29}$. In this context, in which growing needs and multiple demands emerge, studies on the delimitation of bioethical problems in the venue of the family health strategy are extremely relevant and necessary.

Nevertheless, although apparently less obvious if compared to bioethical problems that permeate hospital institutions, there are questions related to the extent of primary health care that corrupt the appropriate work process and the promotion of integrity of care. For example, it is important to mention the limits of team intervention in the ways of life of families or users, difficulties in maintaining privacy in domiciliary services and in delimiting the specialties and responsibilities of each professional, and lack of companionship and collaboration among team members. In agreement with studies carried out by other authors, especially Zoboli and Fortes $(2004)^{20}$, the present study reaffirms that in several aspects, despite the numerous bioethical problems listed, many family health strategy professionals still have great difficulties in recognizing and/or differentiating, in a given context, a problem of bioethical nature. Such a fact goes 
back to what Schramm ${ }^{63}$ delimits as the starting point for the evaluation and resolution of ethical conflicts: identification and clear description of the problem.

Bioethics, as regards the family health strategy, brings a possibility of approaching and describing moral-related issues, as well as constituting, per se, an appropriate reference system for prescribing conducts and basing decision-making processes, in face of the special challenges of primary care and the interaction capacity of the professionals with the reality of the context in which they are inserted. Thus, it can be suggested that for the consolidation of the SUS [Brazilian Unified Health System], in terms of integrity of care and human dignity, redirecting clinical practice in the family is not enough; however, ethics is necessary to broaden the space for discussion of bioethical principles, beginning with students of technical courses and undergraduate courses of study, for optimization of moral judgment and ethical decision making.

This study was received by the Programa de Pós-graduação em Bioética Ética Aplicada e Saúde Coletiva (PPGBIOS) [Graduate Program in Bioethics, Applied Ethics and Collective Health], in association by Universidade Federal do Rio de Janeiro (UFRJ), Fundação Oswaldo Cruz (Fiocruz), Universidade do Estado do Rio de Janeiro (UERJ) e Universidade Federal Fluminense (UFF) [Federal University of Rio de Janeiro, Oswaldo Cruz Foundation, University of Rio de Janeiro and Federal Fluminense University]. The article is part of the dissertation of L. C. S. Motta, referring to the research project, 'Bioethics in the formation of the health professional: building discourse and praxis in the space-time of family health strategy', subsidized by the Conselho Nacional de Desenvolvimento Científico e Tecnológico (CNPq) [National Council for Scientific and Technological Development] and by the Fundação Arthur Bernardes (FUNARBE) [Arthur Bernardes Foundation].

\section{Referências}

1. Silva KB, Bezerra AFB, Tanaka OY. Direito à saúde: uma discussão sobre os desafios e caminhos para sua efetivação. Interface. 2012;16(40):249-59.

2. Uchimura KY, Bosi MLM. Habilidades e competências entre trabalhadores da Estratégia Saúde da Família. Interface. 2012;16(40):149-60.

3. Linard AG, Castro MM, Cruz AKL. Integralidade da assistência na compreensão dos profissionais da Estratégia Saúde da Família. Rev Gaúcha Enferm. 2011;32(3):546-53.

4. Junqueira TS, Cotta RMM, Gomes RC, Silveira SFR, Siqueira-Batista R, Pinheiro TMM et al. Saúde, democracia e organização do trabalho no contexto do Programa Saúde da Família: desafios estratégicos. Rev Bras Educ Med. 2009;33(1)122-33.

5. Campos CEA. O desafio da integralidade segundo as perspectivas da vigilância da saúde e da saúde da família. Cienc Saude Coletiva. 2003;8(2)569-84.

6. Giovanella L, Mendonça MHM, Almeida PF, Scorel S, Senna MCM, Fausto MCR et al. Saúde da Família: limites e possibilidades para uma abordagem integral de atenção primária à saúde no Brasil. Cienc Saude Coletiva. 2009;14(3):783-94.

7. Brasil. Ministério da Saúde. Política Nacional de Promoção da Saúde. [Internet]. 3ạ ed. Brasília: Ministério da Saúde; 2006. v. 7. Disponível: http://bvsms.saude.gov.br/bvs/publicacoes/politica_ nacional_promocao_saude_3ed.pdf

8. Schramm FR, Palácios $M$, Rego $S$. O modelo bioético principialista para análise da moralidade da pesquisa científica envolvendo seres humanos ainda é satisfatório? Ciênc Saúde Coletiva. 2008;13(2):361-70.

9. Siqueira-Batista R, Gomes AP, Rôças G. Ética para todos os seres e ecologia profunda: um preliminar diálogo com relevância para a saúde pública. Cad Saúde Colet. 2009;17(3):559-74.

10. Siqueira-Batista R. O cuidado integral em questão: diálogos entre filosofia e medicina. Rev Bras Med. 2010;47(3):273-75.

11. Rego $S$, Gomes AP, Siqueira-Batista R. Bioética e humanização como temas transversais na formação médica. Rev Bras Educ Med. 2008;32(4):482-91.

12. Marins JJN, Rego S, Lampert JB, Araújo JGC. Educação médica em transformação: instrumentos para a construção de novas realidades. São Paulo: Hucitec; 2004.

13. Cortina A. ética aplicada y democracia radical. 3a ed. Madrid: Tecnos; 2001.

14. Dejeanne S. Os fundamentos da bioética e a teoria principialista. Thaumazein. 2011;4(7):32-45.

15. Jungues JR, Schaefer R, Nora CRD, Basso M, Silocchi C, Souza MC et al. Hermenêutica dos problemas éticos percebidos por profissionais da atenção primária. Rev. bioét. (Impr.). 2012;20(1):97-105.

16. Zoboli ELCP. Bioética e atenção básica: para uma clínica ampliada, uma Bioética clínica amplificada. O Mundo da Saúde. 2009;33(2):195-204.

17. Lima CA, Oliveira APS, Macedo BF, Dias OV, Castro SM. Relação profissional-usuário de saúde da família: perspectiva da bioética contratualista. Rev. bioét. (Impr.) 2014;22(1):152-60.

18. Motta LCS, Vidal SV, Siqueira-Batista R. Bioética: afinal o que é isto? Rev Bras Clin Med. 2012;10(5):367-1. 
19. Siqueira-Batista R, Schramm FR. A Bioética da proteção e a compaixão laica: o debate moral sobre a eutanásia. Cienc Saúde Coletiva. 2009;14(4):1241-50.

20. Zoboli ELCP, Fortes PAC. Bioética e atenção básica: um perfil dos problemas éticos vividos por enfermeiros e médicos do Programa Saúde da Família, São Paulo, Brasil. Cad Saúde Pública. 2004;20(6):1690-9.

21. Schramm FR, Kottov M. Principios bioéticos en salud pública: limitaciones y propuestas. Cad Saúde Pública. 2001;17(4):949-56.

22. Brasil. Ministério da Saúde. Sala de apoio à situação estratégica. [Internet]. [acesso 19 jun 2012]. Disponível: http://189.28.128.178/sage/

23. Brasil. Ministério da Saúde. Saúde da família: uma estratégia para reorientação do modelo assistencial. Brasília: Ministério da Saúde; 1997.

24. Beauchamp TL, Childress JF. Principles of biomedical ethics. 5a ed. New York: Oxford University Press; 2012.

25. Minayo MCS. Pesquisa social: teoria, método e criatividade. 21a ed. Petrópolis: Vozes; 1994. p. 21.

26. Minayo MCS. O desafio do conhecimento: pesquisa qualitativa em saúde. 10a ed. São Paulo: Hucitec; 2007.

27. Costa MAF, Costa MFB. Projeto de Pesquisa: entenda e faça. Petrópolis: Vozes; 2011. p. 19-58.

28. Medeiros CRG, Junqueira AGW, Schwingel G, Carreno I, Jungles LAP, Saldanha OMFL. A rotatividade de enfermeiros e médicos: um impasse na implementação da Estratégia Saúde da Família. Cienc Saude Coletiva. 2010;15(1 Suppl):1521-31.

29. Costa GD, Cotta RMM, Ferreira MLSM, Reis JR, Franceschini SCC. Saúde da família: desafios no processo de reorientação do modelo assistencial. Rev Bras Enferm. 2009;62(1):113-8.

30. Cotta RMM, Schott M, Azevedo CM, Francschini SCC, Priore SE, Dias G. Organização do trabalho e perfil dos profissionais do Programa Saúde da Família: um desafio na reestruturação da atenção básica em saúde. Epidemiol Serv Saúde. 2006;15(3):7-18.

31. Scorel S, Giovanella L, Mendonça MHM, Senna MCM. O Programa Saúde da Família e a construção de um novo modelo de atenção básica no Brasil. Rev Panam Salud Publica. 2007;21(2-3):164-76.

32. Junqueira TS, Cotta RMM, Gomes RC, Silveira SFR, Siqueira-Batista, Pinheiro TMM et al. As relações laborais no âmbito da municipalização da gestão em saúde e os dilemas da relação expansão/precarização do trabalho no contexto do SUS. Cad Saúde Pública. 2010;26(5):918-28.

33. Bardin L. Análise de conteúdo. Lisboa: Edições 70; 2011.

34. Brasil. Conselho Nacional de Saúde. Resolução no 466, de 12 de dezembro de 2012. Diretrizes e normas regulamentadoras para pesquisa envolvendo seres humanos. Brasília: Ministério da Saúde; 2012.

35. Goldim JR. Bioética: índice geral de textos, resumos, definições, normas e casos. [Internet]. [acesso 19 jun 2012]. Disponível: http://www.ufrgs.br/bioetica/confiden.htm

36. Saliba NA, Garbin CAS, Silva FSJFB, Prado RL. Agente comunitário de saúde: perfil e protagonismo na consolidação da atenção primária à saúde. Cad Saude Colet. 2011;19(3):318-26.

37. Seaone A, Fortes PAC. A percepção do usuário do Programa de Saúde da Família sobre a privacidade e a confidencialidade das informações reveladas ao Agente Comunitário de saúde. In: Barchifontaine CP, Zoboli ELCP, organizadores. Bioética, vulnerabilidade e saúde. São Paulo: Idéias \& Letras; 2007. p. 295-323.

38. Seaone AF, Fortes PAC. A percepção do usuário do Programa Saúde da Família sobre a privacidade e a confidencialidade de suas informações. Saúde Soc. 2009;18(1):42-9.

39. Nascimento EPL, Correa CRS. O agente comunitário de saúde: formação, inserção e práticas. Cad Saude Pub. 2008;24(6):1304-13.

40. Fontoura MD, Almeida AP, Marques CMS, Prado MM, Portillo JAC. Dilemas bioéticos no cotidiano do trabalho do agente comunitário de saúde. Rev Saúde Dist Fed. 2004;15(3-4):67-77.

41. Junges JR, Recktenwald M, Herbert NDR, Moretti AW, Tomasini F, Pereira BNK. Sigilo e privacidade das informações sobre usuários nas equipes de atenção básica à saúde: revisão. Rev. bioét. (Impr.). 2015;23(1):200-6.

42. Vidal SV, Motta LCS, Siqueira-Batista R. Agentes comunitários de saúde: aspectos bioéticos e legais do trabalho vivo. [Internet]. Saude Soc. 2015 [acesso 7 mar 2015];24(1):129-40. Disponível: http://www.scielo.br/scielo.php?pid=S0104-12902015000100129\&script=sci_arttext

43. Matumoto S, Mishima SM, Pinto IC. Saúde Coletiva: um desafio para a enfermagem. [Internet]. Cad Saude Publica. 2001 [acesso 19 jun 2012];17(1):233-41. Disponível: http://www.scielosp. $\mathrm{org} / \mathrm{pdf} / \mathrm{csp} / \mathrm{v} 17 \mathrm{n} 1 / 4080 . \mathrm{pdf}$

44. Silva IZQJ, Trad LAB. O trabalho em equipe no PSF: investigando a articulação técnica e a interação entre os profissionais. Interface. 2005;9(16):25-38.

45. Silva LL, Feliz SBCM. Gerência e trabalho em equipe na atenção primária. In: Archancjo DR, Archanjo LR, Silva LL, organizadores. Saúde da Família na atenção primária. Curitiba: Ipex; 2007. p.75-98.

46. Deleuze G. Post-scriptum sobre as sociedades de controle. In: Deleuze G. Conversações 19721990. Rio de Janeiro: Editora 34; 1992.

47. Siqueira-Batista R, Batista RS. Os anéis da serpente: a aprendizagem baseada em problemas e as sociedades de controle. Cienc Saude Coletiva. 2009;14(4):1183-92. 
48. Foucault M. Ditos e escritos IV: estratégia, poder-saber. Rio de Janeiro: Forense Universitária; 1977.

49. Batista MB, Soares MTAM, Soares SP, Porto D. Conhecimento e percepções sobre bioética em uma amostra da população em Brasília. Revista Brasileira de Bioética. 2009;5(1-4):106-25.

50. Kottow M. Bioética y biopolítica. Revista Brasileira de Bioética. 2005;1(2):110-21.

51. Siqueira-Batista R, Rôças G, Gomes AP, Albuquerque VS, Araújo FMB, Messeder JC. Ecologia na formação dos profissionais de saúde: promoção do exercício da cidadania e reflexão crítica comprometida com a existência. Rev Bras Educ Med. 2009;33(2):271-5.

52. Guimarães FT. Educação ambiental como domínio da promoção da saúde: conversações pedagógicas no âmbito da Estratégia de Saúde da Família [dissertação]. Nilópolis: IFRJ; 2010.

53. Dias EC, Rigotto RM, Augusto LGS, Cancio J, Hoefel MGL. Saúde Ambiental e saúde do trabalhador na atenção primária à saúde, no SUS: oportunidades e desafios. Cienc Saude Coletiva. 2009;14(6):2061-70.

54. Palácios M, Rego STA. Bioética e saúde ambiental: algumas questões para discussão. Cad Saude Coletiva. 2009;17(3):489-92.

55. Oliveira CA, Palácios M. Diferentes abordagens sobre ética ambiental. Cad Saude Coletiva. 2009;17(3):493-510.

56. Brasil. Conselho Nacional de Educação. Resolução CNE/CES no 3, de 20 de junho de 2014. Institui Diretrizes Curriculares Nacionais do Curso de Graduação em Medicina e dá outras providências. [Internet]. 2014 [acesso 26 jun 2014]. Disponível: http://portal.mec.gov.br/index. php?option=com_content\&id=12991:diretrizes-curriculares-cursos-de-graduacao

57. Brasil. Conselho Nacional de Educação. Resolução CNE/CES no 4, de 19 de fevereiro de 2002. Institui Diretrizes Curriculares Nacionais do Curso de Graduação em Fisioterapia. [Internet]. 2002 [acesso 26 jun 2014]. Disponível: http://portal.mec.gov.br/index.php?option=com_ content\&id=12991:diretrizes-curriculares-cursos-de-graduacao

58. Brasil. Conselho Nacional de Educação. Resolução CNE/CES no 3, de 7 de novembro de 2001. Institui Diretrizes Curriculares Nacionais do Curso de Graduação em Enfermagem. [Internet]. 2001 [acesso 26 jun 2014]. Disponível: http://portal.mec.gov.br/index.php?option=com_ content\&id=12991:diretrizes-curriculares-cursos-de-graduacao

59. Brasil. Conselho Nacional de Educação. Resolução CNE/CES no 3, de 19 de fevereiro de 2002. Institui Diretrizes Curriculares Nacionais do Curso de Graduação em Odontologia. [Internet]. [acesso 26 jun 2014]. Disponível: http://portal.mec.gov.br/index.php?option=com_ content\&id=12991:diretrizes-curriculares-cursos-de-graduacao

60. Ceccim RB. Educação permanente em saúde: descentralização e disseminação de capacidade pedagógica na saúde. Cienc Saude Coletiva. 2005;10(4):975-86.

61. Vidal SV, Motta LCS, Gomes AP, Siqueira-Batista R. Problemas bioéticos na Estratégia Saúde da Família: reflexões necessárias. Rev. bioét. (Impr.). 2014;22(2):347-57.

62. Vidal SV, Gomes AP, Maia PM, Gonçalves LLG, Rennó L, Motta LCS et al. A Bioética e o trabalho na estratégia saúde da família: uma proposta de educação. Rev Bras Educ Med. 2014;38(3):372-80.

63. Schramm FR. Bioética da proteção: justificativas e finalidades. latrós. 2005;1:121-30.

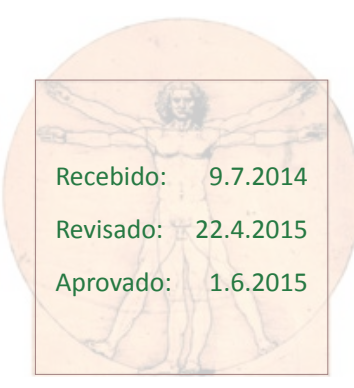




\section{ANEXO}

\section{Questionário}

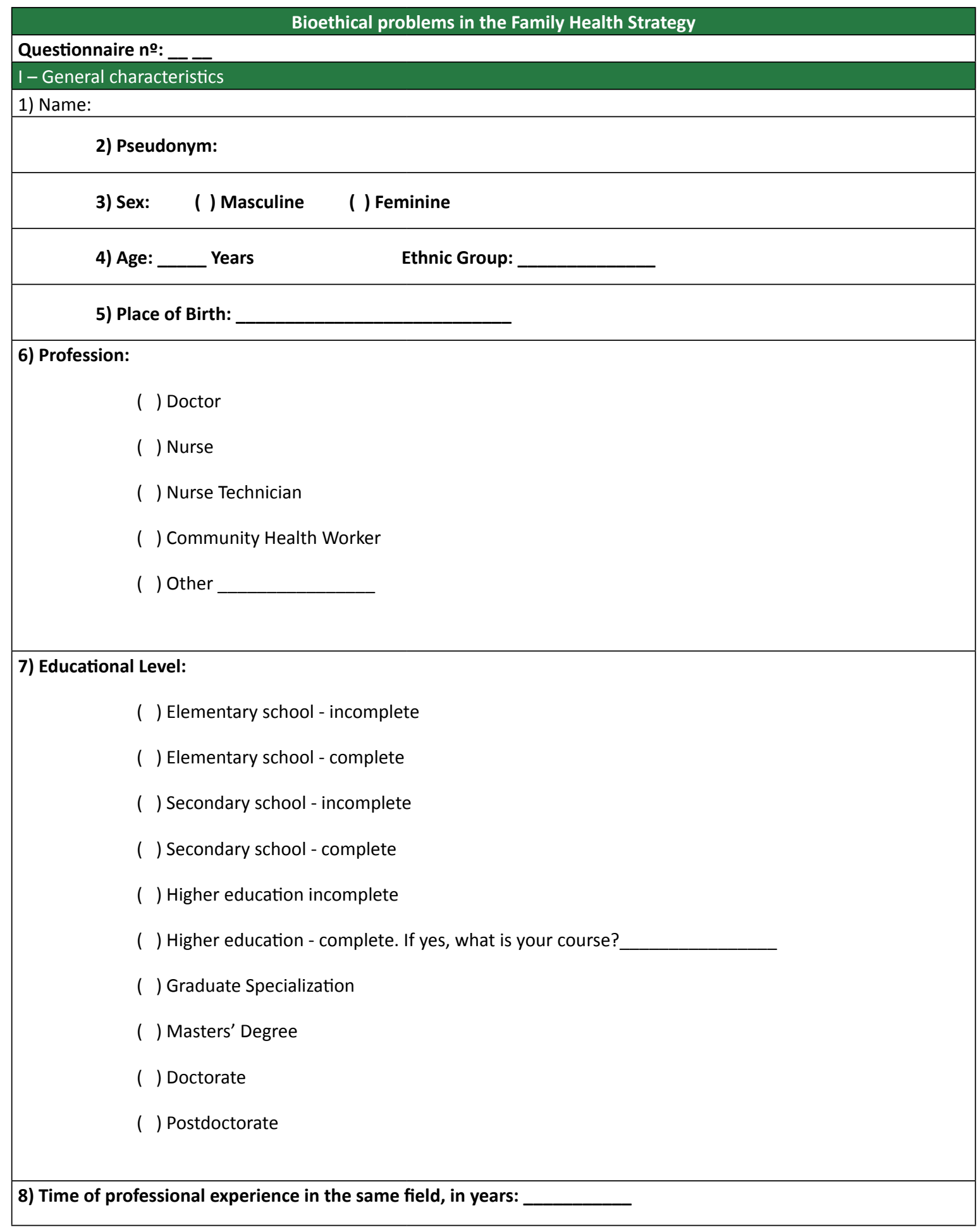


9.1) Total time working in Family Health:

$$
\begin{aligned}
& \text { ( ) } 0-1 \text { year } \\
& \text { ( ) } 1-2 \text { years } \\
& \text { ( ) } 2-5 \text { years } \\
& \text { ( ) } 6-10 \text { years } \\
& \text { ( ) } 11-15 \text { years } \\
& \text { ( ) Don't know }
\end{aligned}
$$

9.2) Time working in the ESF - Family Health Strategy (former - PSF):

$$
\begin{aligned}
& \text { ( ) } 0-1 \text { year } \\
& \text { ( ) } 1-2 \text { years } \\
& \text { ( ) } 2-5 \text { years } \\
& \text { ( ) } 6-10 \text { years } \\
& \text { ( ) } 11-15 \text { anos } \\
& \text { ( ) Don't know }
\end{aligned}
$$

II - BIOETHICAL PROBLEMS FACED BY THE TEAM

10) Describe situations experienced in your department, in which you think there were problems of an ethical and/ or bioethical nature.

11) How did the team approach the problem(s) described above?

12) Was it necessary to refer to some bibliographical reference (text, article, codes of ethics or other) or to some consultant to help resolve the issue(s)? Which ones?

13) Was there a solution to the problem(s)? What solution(s)?

14) From your viewpoint, what were the principal consequences of the problem(s) of an ethical and bioethical nature listed?

III - KNOWLEDGE OF CONCEPTS OF ETHICS AND BIOETHICS

15) What is the first word that comes to your mind when you hear the term ethics?

16) What is the first word that comes to your mind when you hear the term bioethics?

17) Do you know any concept of ethics and bioethics? If yes, what or which?

18) What do you understand by ethics?

19) What do you understand by bioethics?

20) Have you heard of or read of concepts such as respect for autonomy, beneficence, non-maleficence, justice, protection, compassion? Any others?

21) All health professionals should have their work guided by principles of ethics and bioethics. What is your perception of this affirmation? Comment.

22) Have you ever participated in a course, workshop or other teaching-learning process dealing with ethics and bioethics? When and where?

23) Do you think it is possible to teach ethics and bioethics? If so, how?

24) If you were to set up a course to discuss ethics and bioethics, how would it be organized? 